Nippon Suisan Gakkaishi $\quad$ 75(1), 115 (2009)

\title{
特別シンポジウム記録 生態系サービスと水産
}

\section{参加者コメント \\ 農林水産業の多面的機能の定量的評価に潜む問題}

\author{
谷口旭 \\ 東京農業大学生物産業学部
}

Questions behind quantitative estimation of multifunctionalities of agriculture and fisheries

\section{AKIRA TANIGUCHI}

Faculty of Bioindustry, Tokyo University of Agriculture, Abashiri, Hokkaido 099-2493, Japan

平成 15 年 10 月 8 日, 農林水産大臣は, 地球環境・ 人間生活にかかわる水産業及び漁村の多面的な機能の内 容及び評価について, 日本学術会議会長に諮問した。こ れは，平成 12 年 12 月 14 日に諮問し，平成 13 年 11 月 1 日に答申を受けた「地球環境・人間生活にかかわる農 業及び森林の多面的な機能の評価について」に続くもの であった。平成 12 年の諮問の折には，水産業の多面的 機能に関しても意見を求めたいとの付託が口頭で追加さ れたので，その答申には「水産業・海洋の多面的機能」 が盛り込まれた。ただし，それは 6.5 ページの付論にす ぎなかった。平成 15 年の諮問は, 水産業の多面的機能 について, 改めて学術的に調査審議することを求めるも のであった。学術会議は直ちに答申原案作成を担当する 特別委員会を設置し, 当時の学術会議を組織していた全 7 部から委員を選出して, 学問の全領域から幅広く審議 することとした。当然, 農学分野を担う第 6 部が中心 的役割を果たすことになった。

ふたつの諮問は, いずれも, 多面的機能の内容ととも に, その定量的評価も求めていた。それゆえ, 学術会議 からの答申には, 定量的評価に関する審議結果が付され ている。しかし，その中に記載されている評価值（貨幣 価值）は，学術会議が自ら算出したものではない。たと えば，農業の機能評価については，四つの異なる評価方 法の長所短所を深く論議したものの, 貨幣価值の算出は 民間の研究所に委託したのである。森林および水産業・ 漁村の機能の貨幣価值評価に関しては, 科学的知見がい まだそれを可能とするほどには発達していないこと，今 後評価を試みる者は, 現在の水準の限界をよくよく理解 してことにあたるべきである，と記されたにすぎない。 そのような答申にするという決定までには, 定量的,
特に貨幣価值で評価することの利点と弊害が何度か論議 された。その陰には, 当時出版された, 世界の生態系 サービスを貨幣価值で評価した論文への批判があった。 その内容は以下のようなものであったと, 私は理解して いる。

生態系という自然の営みは，いかなる技術をもってし ても，人類が完全に模倣できるものではない。しかる に，その一部分だけを切り出して評価することは, 自然 の価值を不当に過小評価することになる。もっと危険な ことは，その一部分だけを模倣するに過ぎない技術を過 大に評価することにつながり，いわば工業技術至上主義 ともいうべき風潮を強化するに違いない。それはさら に, 自然の環境と生態系の劣化を加速し, 地球環境問題 を拡大する恐れがある。農林水産業は正しく自然系の中 で営まれるものであり, その背景では, 現在の価值観に 照らせば無価值すなわち評価するに足らないという諸過 程，しかしひとつたりとも欠かすことができない無数の 過程が，作動しているはずである。この産業は，いわば “自然そのもの”である。今日の人類が, 自らの生存の 基盤である自然を貨幣価值で評価できる知恵と能力を持 っているとは, 到底考えられない。

この考え方は, 森林の機能と水産業の機能を担当する 委員に, 特に強かった。定量的評価に潜んでいるこのよ うな危険については, 諮問した農水省もとくと承知して いるとは判っていた。それでも, 社会には, 評価結果を 悪意を持って利用しようとする者がいるかもしれない。 その可能性を無視することはできなかったというのが， 当時の䨌囲気であったと思う。それが, 日本学術会議が あえて自らが定量的評価をすることを避けた理由であっ たと，私は理解した。 